Check for updates

Cite this: RSC Adv., 2018, 8, 15188

Received 29th November 2017 Accepted 17th April 2018

DOI: $10.1039 / c 7 r a 12875 d$

rsc.li/rsc-advances

\section{Mechanical and water-resistant properties of rice straw fiberboard bonded with chemically-modified soy protein adhesive}

\author{
Wanrong Zhang, $\uparrow$ Hongguang Sun, $\uparrow$ Chao Zhu, $\uparrow$ Kai Wan, Yu Zhang, Zhengping Fang \\ and Zhaoquan $\mathrm{Ai}$ (ID *
}

In this work, rice straw and soy protein were used to make fiberboard which may replace wood fiberboard. Soy protein isolates (SPI) were modified by epoxidized oleic acid to improve the soy protein adhesive properties such as adhesion strength and water resistance. The effects of $\mathrm{NaOH}$ content, the addition of modified-SPI adhesives and fiberboard density on the mechanical and water-resistant properties of the rice straw fiberboards were investigated. FTIR and XRD results of modified SPI indicated the epoxidized oleic acid and soy protein reacted with each other. FTIR and SEM images of rice straw fibers showed that $\mathrm{NaOH}$ solution removed the wax layer through chemical etching. The results of investigating mechanical properties and water absorption illustrate that when the soy protein-based adhesives content and density and the hot pressing temperature and pressure of fiberboard are $12 \%, 0.8 \mathrm{~g} \mathrm{~cm}^{-3}, 140{ }^{\circ} \mathrm{C}$ and $6 \mathrm{MPa}$, respectively, the panels have optimal mechanical and water-resistant performances. Moreover, the panels meet the requirements of chinese medium density fiberboard (MDF) Standard of GB/T 117182009. Since biological raw materials are recyclable and biomass, the fiberboard bonded with modified soy protein adhesive has no toxicity and is easily biodegradable. In addition, the rice straw burned to produce haze has been preferably utilized.

\section{Introduction}

It is well-known that environmental problems may arise from the random burning of rice straw. So, great attention has been focused on the utilization of rice straw in recent years. ${ }^{1}$ It has been found that rice straw can be an inexpensive natural lignocellulose resource, and it has the characters of low cost, low density, biodegradability and high toughness with acceptable mechanical properties, ${ }^{2}$ making it a potential candidate to replace wood flour or fiber composites. ${ }^{3,4}$ For example, Yang ${ }^{5}$ used rice straw, wood particles and the commercial urea-formaldehyde resin and prepared a composite board, which has the properties of noise adsorption, thermal insulation, and so on. It may be a good alternative to wood particleboard. El-Kassas and Mourad ${ }^{6}$ also used the commercial urea-formaldehyde resin as a binder to manufacture the rice straw based fiberboards, and explored the influence of the binder mass and the density of straw fiberboard on the fiberboard's performance. Sitz and Bajwa ${ }^{7}$

\footnotetext{
Hubei Collaborative Innovation Center for Advanced Organic Chemical Materials, Ministry of Educational Key Laboratory for the Synthesis and Application of Organic Functional Molecules, College of Chemistry and Chemical Engineering, Hubei University, Wuhan, Hubei, 430062, China. E-mail: 18963962367@163.com; Fax: +86-18963962367; Tel: +86-18963962367

$\dagger$ These three authors contribute equally to this work.
}

used methylene diphenyl diisocyanate (MDI) resin to bond the fibers consisting of soybean straw and wheat straw, and found out that the performance of the blended formulation was comparable to the fiberboard made with wheat straw or soybean straw fiber respectively.

Although the use of straw fiber as a raw material for fiberboard could reduce the environmental stress, some new problems has arisen from the adhesives used..$^{8}$ One of them is the release of formaldehyde from urea-formaldehyde and phenolic resins, which contaminates the environment and is harmful to human health. Using isocyanate adhesives may have low market competitiveness due to its high price.

To solve the above problems, using soy protein adhesives may be a good choice. Soy protein,,$^{9,10}$ as a natural polymeric material, has many advantages such as abundance, renewability, versatility, biodegradability and no toxicity. However, soy protein adhesives has poor water resistance and low adhesion strength. Fortunately, these disadvantages may be overcome by altering soy protein's molecular structure or conformation with chemical ${ }^{11-15}$ and enzymatic agents. ${ }^{16,17}$

In this work, we used rice straw as the raw material and chemically-modified soy protein emulsion as the adhesive to make fiber board. The mechanical and water-resistant properties of this rice straw fiber board were studied. 


\section{Materials and methods}

\subsection{Materials}

Soy protein isolates (SPI) with $90 \%$ protein content was purchased from Zhengzhou Taber Trading Company (China). Sodium hydroxide, urea and epoxidized oleic acid were provided by Sinopharm Chemical Reagent Company (China). The rice straw was harvested in Jingzhou (China), and supplied by the local farmer.

\subsection{Preparation of the chemically-modified soy protein adhesive}

A dispersion consisting of SPI/urea/water ( $2: 1: 25$, by weight) was prepared first, and the $\mathrm{pH}$ of the slurry was then adjusted to 10 with $0.01 \mathrm{~mol} \mathrm{~L}^{-1} \mathrm{NaOH}$. The dispersion was stirred at $65^{\circ} \mathrm{C}$ for 1 hour, then $60 \mathrm{wt} \%$ (weight of SPI) epoxidized oleic acid was added to the dispersion by syringe. After another 2 hours of mixing at the same temperature, the modified soy protein adhesive was prepared (modified SPI). None epoxidized oleic acid was also added to the dispersion as a control (urea pretreated SPI).

\subsection{Pretreatment of the rice straw}

The rice straw was cut into chips with the length of $2 \mathrm{~cm}$ to $4 \mathrm{~cm}$ firstly, and then a juice extractor was used to cut up the straw material. The chopped straw were spread on a newspaper and allowed to dry in open air. Subsequently, different amount of $\mathrm{NaOH}(0 \mathrm{wt} \%, 0.5 \mathrm{wt} \%, 1 \mathrm{wt} \%, 1.5 \mathrm{wt} \%, 2 \mathrm{wt} \%$ ) solution was added to pretreat the fibers for $3 \mathrm{~h}$ under $65{ }^{\circ} \mathrm{C}$. And the fibers was washed with distilled water to remove $\mathrm{NaOH}$ on the fiber. At last, the fibers were left in an air-circulated oven to dry and the average moisture content of the fibers was about $13.0 \%$.

\subsection{Manufacturing of the rice straw fiberboard}

In this process, four factors such as the amount of SPI-based adhesive, density of the straw fiberboard, press temperature and pressure were considered to make a better fiberboard. The pretreated fibers with $13.0 \%$ moisture content were blended with the modified SPI-based adhesives in a plastic pot at room temperature by hands, and the amount of adhesive was 8,10 , 12,14 , and $16 \mathrm{wt} \%$, respectively. According to different density of the straw fiberboard $\left(0.65 \mathrm{~g} \mathrm{~cm}^{-3}, 0.70 \mathrm{~g} \mathrm{~cm}^{-3}, 0.75 \mathrm{~g} \mathrm{~cm}^{-3}\right.$, $0.80 \mathrm{~g} \mathrm{~cm}^{-3}, 0.85 \mathrm{~g} \mathrm{~cm}^{-3}$ ), the mixtures were hot-pressed into fiberboards in a $200 \mathrm{~mm} \times 200 \mathrm{~mm} \times 5 \mathrm{~mm}$ steel mold for $20 \mathrm{~min}$. The press temperature and pressure was $150{ }^{\circ} \mathrm{C}, 6 \mathrm{MPa}$ respectively. In the process of hot pressing, water vapor in the fiberboards should be released regularly. Three replicates for each kind of SPI-based adhesive fiberboard were produced, and panels were placed in a chamber with $65 \%$ relative humidity at room temperature for 48 hours for further analysis.

\subsection{Characterization}

2.5.1 Physiochemical property determination. Fourier transform infrared (FTIR) spectroscopic data were collected using a Perkin Elmer Spectrum one FTIR spectrometer (USA).
Epoxidized oleic acid-modified SPI samples were dried in a vacuum oven and ground for FTIR analysis. The rice straw fiber specimens were scanned between $500 \mathrm{~cm}^{-1}$ and $4000 \mathrm{~cm}^{-1}$.

The general area detection diffraction system (D8 Advance, Bruker Inc. Germany) was used at $40 \mathrm{kV}$ and $40 \mathrm{~mA}$ to study the texture of SPI, epoxidized oleic acid and epoxidized oleic acidmodified SPI. The X-Ray Diffraction (XRD) data were collected over the range of $2 \theta=5-60^{\circ}$ at a rate of $5^{\circ} \mathrm{min}^{-1}$.

Scanning electron microscopy (SEM) observation was carried out on a Field Emission Scanning Electron Microscope (JSM6510LV, Japan). The surface morphology of rice straw fibers before or after $\mathrm{NaOH}$ treatment were observed by SEM, and the surfaces of the fibers were sputtered with gold before the SEM observation. The morphology of internal fibers and adhesive in the fiberboard was also observed by this method.

Thermogravimetric analysis (TGA) measurements were carried out using a thermogravimetric analyzer Diamond TG/ DTA (Perkin Elmer, USA), operating from room temperature to $900{ }^{\circ} \mathrm{C}$ at the rate of $20{ }^{\circ} \mathrm{C} \mathrm{min}^{-1}$, and under nitrogen atmosphere. The sample weight in all tests was approximately 5-8 mg.

2.5.2 Mechanical properties and water absorption properties. Rectangular $150 \mathrm{~mm} \times 50 \mathrm{~mm}$ pieces were used to determine three-point bending measurement of modulus of rupture (MOR) and modulus of elasticity (MOE), and square pieces of $50 \mathrm{~mm} \times 50 \mathrm{~mm}$ were used for internal bond strength (IB) measurement. A $10 \mathrm{kN}$ electronic universal testing machine (WDW-10, Fangyuan test corporation, Jinan, China) was used to determine the mechanical properties of SPI-based adhesive fiberboard.

Square pieces of $50 \mathrm{~mm} \times 50 \mathrm{~mm}$ were used for thickness swilling (TS) and water absorption (WA) test, all the specimens should be soaked in distilled water at $25{ }^{\circ} \mathrm{C}$ for 24 hours.

\section{Results and discussion}

\subsection{The properties of the chemically-modified soy protein adhesive}

3.1.1 FTIR analysis. In order to prove the reaction between the epoxy groups of epoxidized oleic acid and amino groups of SPI, the sample of SPI and modified-SPI were characterized by FTIR analysis.

Fig. 1 shows that the broad peak around $3400 \mathrm{~cm}^{-1}$ corresponds to free and bound $\mathrm{N}-\mathrm{H}$ and $\mathrm{O}-\mathrm{H}$ groups. ${ }^{18}$ The peak observed at about $2930 \mathrm{~cm}^{-1}$ is attributed to $\mathrm{C}-\mathrm{H}$ stretching vibrations of methyl groups in SPI adhesives. Some other characteristic absorption peaks such as $1650 \mathrm{~cm}^{-1}, 1537 \mathrm{~cm}^{-1}$ and $1240 \mathrm{~cm}^{-1}$ in the figure belongs to $\mathrm{C}=\mathrm{O}$ stretching vibration (amide $\mathrm{I}$ ), $\mathrm{N}-\mathrm{H}$ bending vibration (amide $\mathrm{II}$ ), and $\mathrm{N}-\mathrm{H}$ in plane and $\mathrm{C}-\mathrm{N}$ stretching vibration (amide $\mathrm{III}),{ }^{19}$ respectively. The epoxidized oleic acid used has many free epoxy groups that could react with the active amino groups in SPI molecular. Comparing epoxidized oleic acid modified SPI and SPI adhesive, the IR absorption peak at $1537 \mathrm{~cm}^{-1}$ disappears and the peak at $1204 \mathrm{~cm}^{-1}$ increases significantly, confirming the reaction between the epoxy groups of epoxidized oleic acid and 


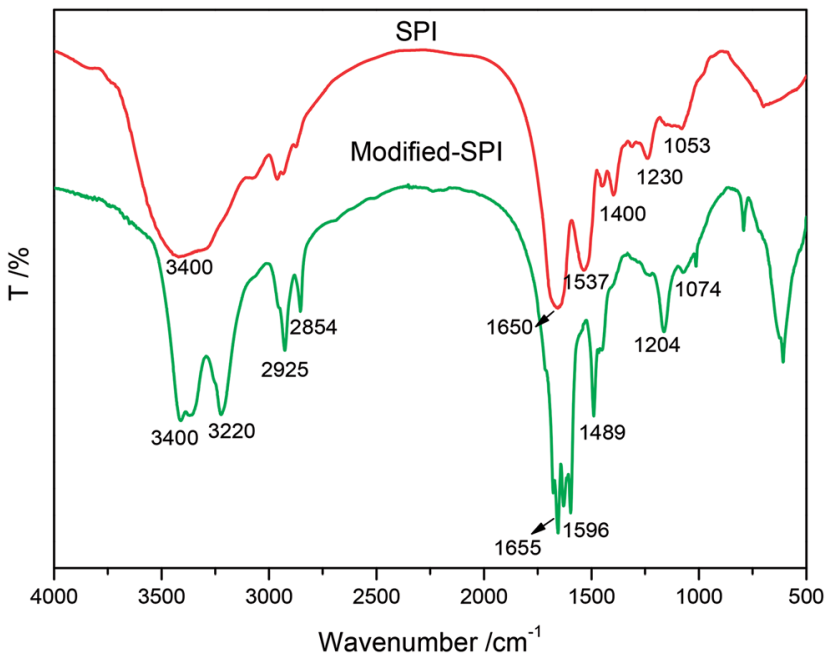

Fig. 1 FTIR of the SPI and epoxidized oleic acid modified soy protein adhesive.

amino groups of SPI. A new absorption peak was observed at $1489 \mathrm{~cm}^{-1}$ and the enhanced absorption peaks at $2925 \mathrm{~cm}^{-1}$ and $2854 \mathrm{~cm}^{-1}$ were attributed to epoxidized oleic acid. In addition, because of the hydrogen bonding interaction between carboxyl groups of epoxidized oleic acid and amino groups, hydroxyl groups in SPI, two or more absorption peaks were formed at $3400 \mathrm{~cm}^{-1}$ and $1650 \mathrm{~cm}^{-1}$.

3.1.2 XRD analysis. To further study the effect of epoxidized oleic acid in modified soy protein, the phase components of SPI, urea pretreated SPI, and modified soy protein were determined by XRD.

In Fig. 2 the pure SPI showed two diffuse X-ray peaks at the $2 \theta$ angle of approximately $9^{\circ}$ and $19^{\circ}$. The two feature angles are respectively corresponding to the $\alpha$-helix and $\beta$-sheet structures of soy protein.$^{20}$ This result illustrates that soy protein has a low degree of crystallization. After urea and $\mathrm{NaOH}$ pretreatment (urea pretreated SPI), the peak intensities at $2 \theta$ angle about $9^{\circ}$

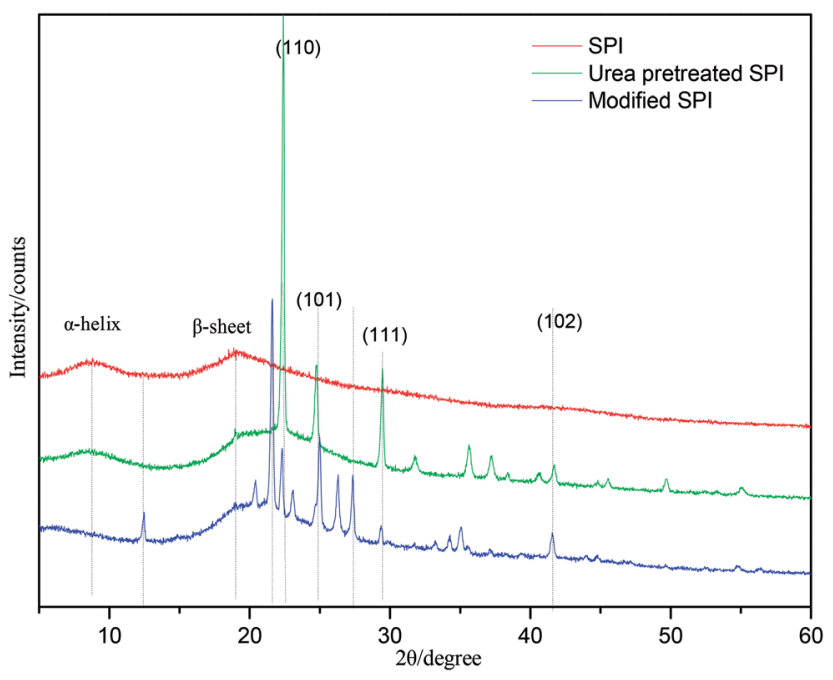

Fig. 2 XRD of the SPI, urea pretreated SPI, and modified soy protein. and $19^{\circ}$ decreased obviously, indicating that the globular structure of soy protein molecular was unfolded by urea and $\mathrm{NaOH}$. As a result, more and more active groups were exposed and beneficial to the reaction between epoxidized oleic acid and SPI molecular, due to the irregular arrangement of the soy protein molecule. The XRD of modified SPI showed that the peak at $2 \theta$ of $9^{\circ}$ disappeared but also a new XRD peak appeared at approximately $12.5^{\circ}$ when epoxidized oleic acid was introduced, which confirmed the reaction between the epoxidized oleic acid and soy protein. The new peak belongs to epoxidized oleic acid.

\subsection{Effect of $\mathrm{NaOH}$ pretreatment on straw fiber and fiberboard properties}

3.2.1 FTIR analysis. Water-based adhesives such as SPI could not effectively wet the straw surface due to the hydrophobic wax and inorganic silica layer on the outer surface of the rice straw. ${ }^{21}$ So the wax layer should be removed before hot pressing process. Fig. 3 is the FTIR result of straw fires before and after treated by $1 \mathrm{wt} \% \mathrm{NaOH}$.

From Fig. 3, it is disclosed that there are little chemical groups changes on the surface of the two different straw fibers. But under the range of $1000-1500 \mathrm{~cm}^{-1}$ and around $2900 \mathrm{~cm}^{-1}$, the intensity of intensity of absorption peak from $\mathrm{NaOH}$ pretreated straw fiber was weaker than that from untreated fibers. The methyl and methylene and hydrogen bond in the lignin or cellulose of the fibers are more broken after $\mathrm{NaOH}$ pretreatment because of the destruction of wax layer on the straw fiber surface, which makes it possible to accelerate the adsorption of modified-SPI adhesive and then increases the penetrating rate.

3.2.2 SEM analysis. SEM can intuitively prove the damaging effect of sodium hydroxide on the surface of straw fiber wax and the fractured surface of straw fiber with modifiedSPI adhesives. According to the results of performance measurement. Several sets of experiments with better comprehensive property are selected as follows:

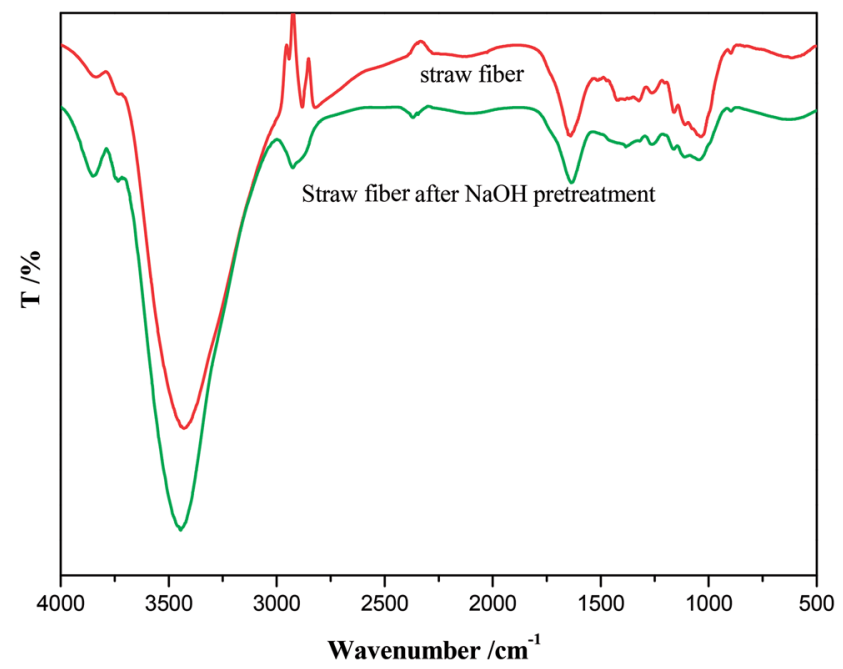

Fig. 3 FTIR of straw fibers and straw fibers treated by 1 wt\% $\mathrm{NaOH}$. 

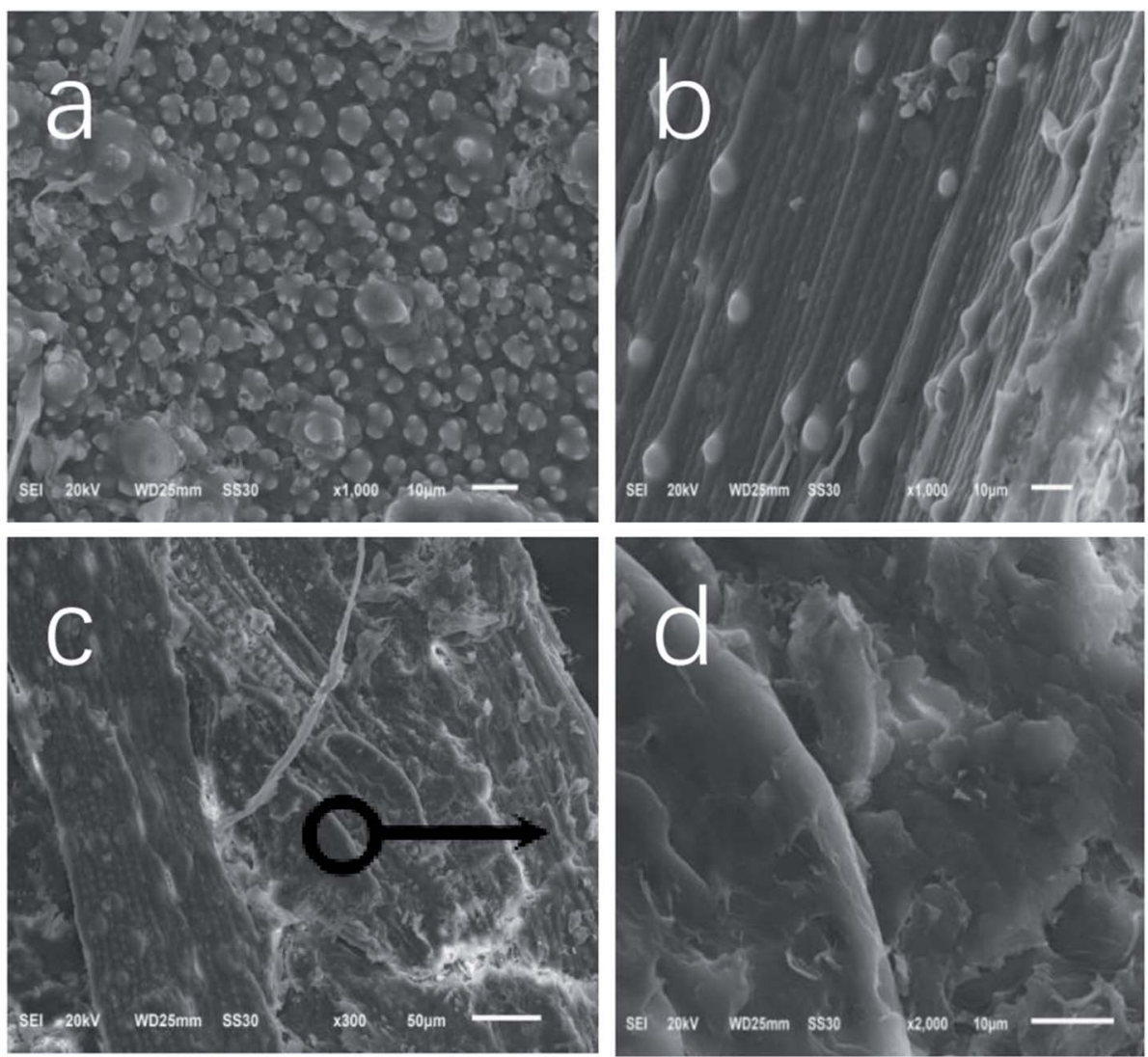

Fig. 4 SEM micrographs of straw fibers treated by $1 \mathrm{wt} \% \mathrm{NaOH}$ before (a) and after (b); SEM of rice straw fiberboard with modified-SPI adhesives (c and d).

Fig. 4 shows the SEM images of rice straw fibers before and after alkali pretreatment. In Fig. 4a, there are a lot of wax protuberances on the surface of the rice straw fibers, and the regular arrangement of protuberance can prevent SPI adhesive spreading and permeating into the fibers. But in Fig. $4 \mathrm{~b}$ the wax protuberance becomes fewer after $\mathrm{NaOH}$ treatment, which illustrates that $\mathrm{NaOH}$ solution could damage the waxy layer through chemical etching, ${ }^{22,23}$ and also proves that the band intensity of hydroxyl groups gets stronger than that in untreated fibers at $3200-3500 \mathrm{~cm}^{-1}$ in Fig. 3.
The SEM images in Fig. 4c and d were the fractured surface of straw fiberboards bonded with modified-SPI adhesives in different magnification. From Fig. $4 \mathrm{c}$ one can see that the fibers became straight, were distributed orderly after the hot press processing, and the fibers were combined closely and covered fully by the adhesives. Fig. $4 \mathrm{~d}$ showed the fractured surface of straw fiberboards at higher magnification. It could be observed obviously from the micrograph that modified-SPI adhesives intimated contacts with the fibers. When the straw fiberboard was broken, the cured adhesives in fibers was also broken, and
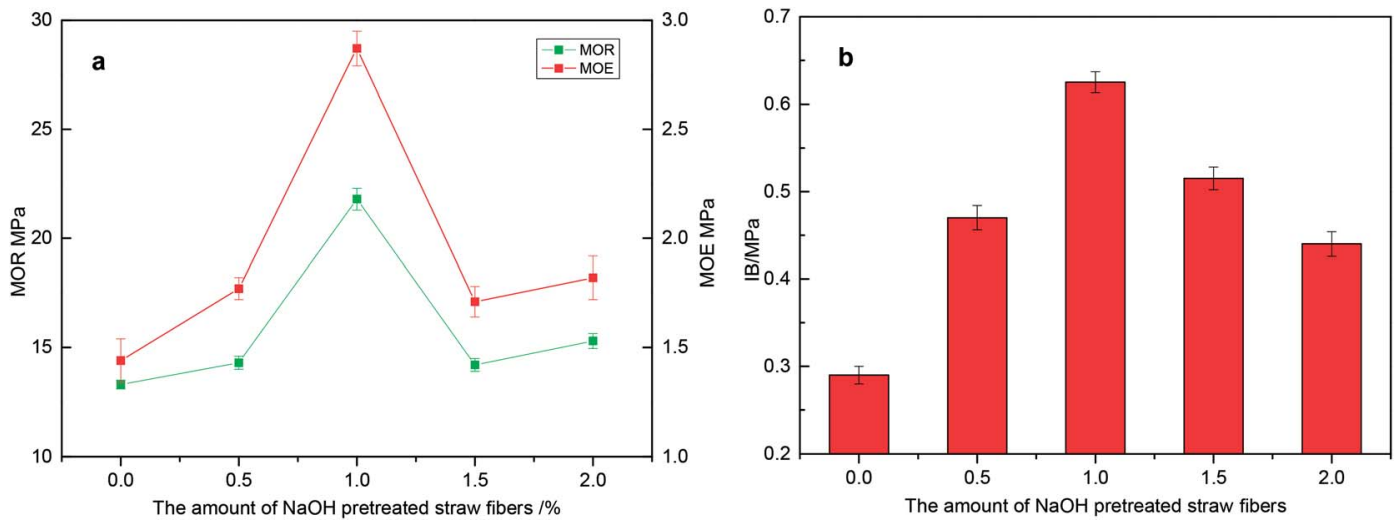

Fig. 5 Effect of $\mathrm{NaOH}$ addition on the MOR, MOE (a) and IB of the straw fiberboards (b). 


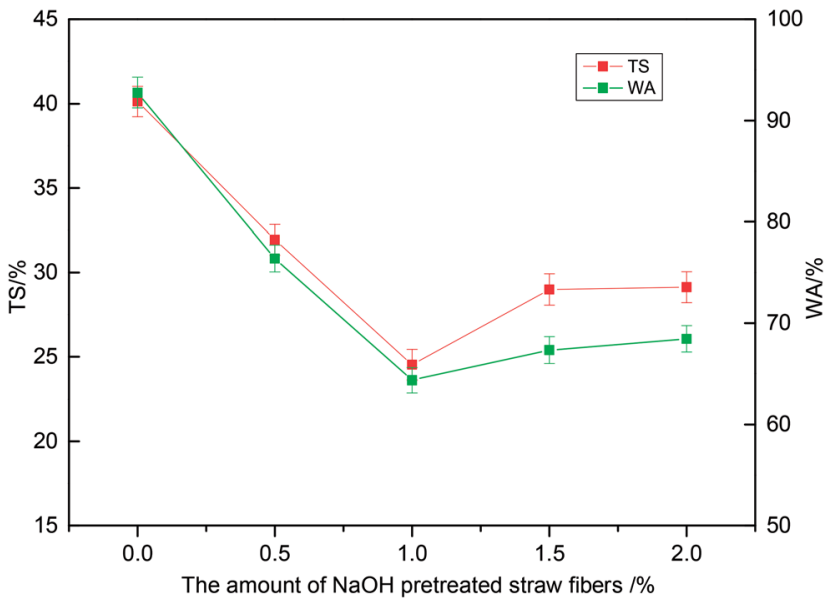

Fig. 6 Effect of $\mathrm{NaOH}$ addition on TS and WA of the straw fiberboards.

the surface of broken point was coarse. These observations indicated that the protein-based adhesives permeated into the fibers and there might be chemical interactions between the exposed hydroxyl groups of cellulose and lignin in pretreated fibers and the polar groups of soy proteins and resulted in better mechanical interlocking. This might be one of reasons that straw fiberboards had good mechanical and water-resistant properties.

\subsection{Effect of $\mathrm{NaOH}$ addition on mechanical properties of the straw fiberboards with modified-SPI adhesives}

3.3.1 Effect of NaOH addition on the MOR, MOE and IB of the straw fiberboards with modified-SPI adhesives. The effect of $\mathrm{NaOH}$ treatment on mechanical properties of SPI-bonded rice straw fiberboards are presented in Fig. 5. As we can see, the straw fiberboard has the highest MOR value of 21.8 MPa and MOE value of $2.87 \mathrm{GPa}$ after $1 \mathrm{wt} \% \mathrm{NaOH}$ treatment (in Fig. 5a). It is likely that the wax layer was damaged adequately and some active groups were exposed under this $\mathrm{NaOH}$ content. Therefore the modified-SPI adhesives can permeate into the fibers easily and result in better mechanical interlocking. Polar groups from the modified SPI adhesive also have a good interaction with the exposed active groups in fiber's substrate. The IB value determines the quality of adhesives and the type of substrates in which it can be used. ${ }^{24}$ As shown in Fig. 5b, the hot-pressed straw fiberboards had the highest IB value when 1 wt $\%$ amount of $\mathrm{NaOH}$ pretreated the straw fibers. If the content of $\mathrm{NaOH}$ is more than $1 \mathrm{wt} \%$, the decrease in MOR, MOE and IB value could be a result of the fact that, besides the damage of the wax layer on the straw fiber surface, lignin and cellulose also have been hydrolyzed, leading to the much brittle straw fibers and the poor mechanical properties of the fiberboards. It may be an experimental mistake that the MOR and MOE value increased a little when $2 \mathrm{wt} \% \mathrm{NaOH}$ was used to pretreat the straw fibers.

3.3.2 Effect of NaOH addition on TS and WA of the straw fiberboards with modified-SPI adhesives. Thickness swelling (TS) percentages and water absorption (WA) percentages of SPIbonded fiberboards after 24 hours are displayed in Fig. 6. Two values are influenced by the interactions between the fibers and adhesives. When $1 \mathrm{wt} \% \mathrm{NaOH}$ was used to pretreat the rice straw fibers, the fiberboard had a good water resistance, with a TS value of $24.53 \%$ and WA value of $64.35 \%$, respectively. This result agreed well with the data in Fig. 5. From this figure we can also see that, the increase in $\mathrm{NaOH}$ content from $1 \mathrm{wt} \%$ to $2 \mathrm{wt} \%$ reduces the water resistance of the produced straw fiberboards. When more $\mathrm{NaOH}$ was added to pretreat the straw fibers, not only the wax layer was damaged, but also lignin and cellulose were hydrolyzed. This means that more hydrophilic groups were produced, and naturally the value of TS or WA increased. ${ }^{25}$

\subsection{Effect of modified-SPI adhesives content on mechanical properties of the straw fiberboards}

3.4.1 Effect of modified-SPI adhesives on the MOR, MOE and IB of the straw fiberboards. After the optimum amount of $1.0 \% \mathrm{NaOH}$ was determined, the amount of modified-SPI adhesives is also an important factor affecting the mechanical properties of fiberboard. According to the test results in Fig. 7a and $b$, the MOR and MOE of fiberboards increased with the increasing of modified-SPI adhesives added. This phenomena may be a result of more numbers of bonding points formed between fibers with the increasing of modified-SPI adhesives,
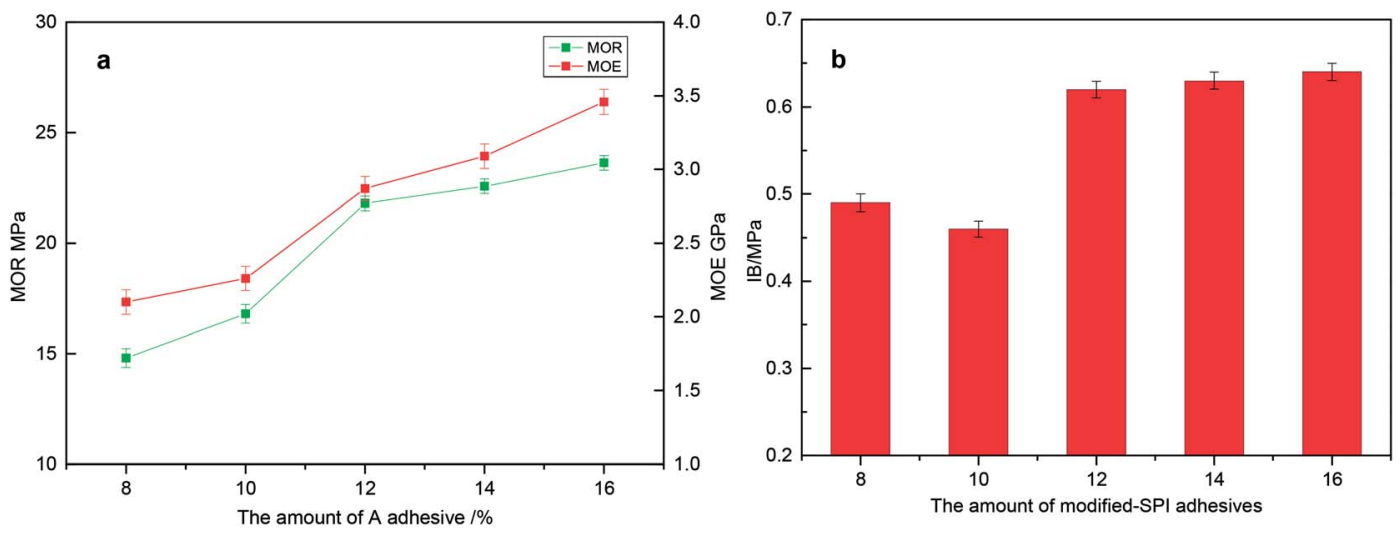

Fig. 7 Effect of modified-SPI adhesives addition on the MOR, MOE (a) and IB (b) of the straw fiberboards. 


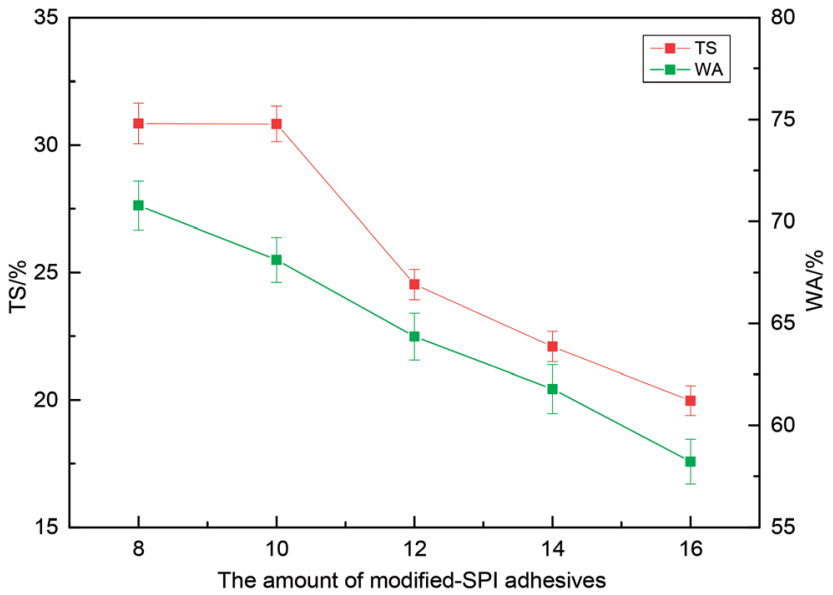

Fig. 8 Effect of modified-SPI adhesives addition on TS and WA of the straw fiberboards.

thus making the fibers a close combination. The IB value in Fig. 7b also increased with the amount of modified-SPI adhesives, and the fiberboards produced with more than $12 \mathrm{wt} \%$ adhesives met the requirements (IB strength was 0.6 MPa). This illustrates that straw fiberboards have good mechanical properties using this modified-SPI adhesives. So considering the preparation cost of the fiberboards, $14 \mathrm{wt} \%$ of modified-SPI adhesive is enough to bond the straw panels. The MOE value under this content of adhesives can meet the standard (MOE $\geq$ 2.6 GPa), and the MOR value is close to this standard (MOR $\geq 26$ $\mathrm{MPa})$.

3.4.2 Effect of modified-SPI adhesives on TS and WA of the straw fiberboards. The results in Fig. 8 showed that increasing the modified-SPI adhesives from $8 \%$ to $16 \%$ reduced the 24 hours TS and WA values of the produced straw fiberboards. Increasing the SPI adhesives content created more numbers of bonding points between fibers, making the fibers contact closely. As a result, water can't get into the fiberboards and separate the fibers. Another possible reason on the TS and WA improvement might be the introduction of hydrophobic groups in modified-SPI adhesives. The reaction between SPI and epoxidized oleic acid could consume hydrophilic amino groups and introduce the long carbon chains. More hydrophobic chains would prevent the moisture entering fiberboards with the increasing of modified-SPI adhesives. When $14 \%$ adhesives were used, the TS value of straw fiberboard was $22 \%$ and much less than the regulation of Chinese MDF Standard $(\leq 35 \%)$.

\subsection{Effect of density on mechanical properties of the straw fiberboards with modified-SPI adhesives}

3.5.1 Effect of fiberboard density on the MOR, MOE and IB of the straw fiberboards with modified-SPI adhesives. It is well known that the density of board is another important factor that may affect the mechanical properties of fiberboard. According to the curves in Fig. 9a and b, MOR and MOE of the straw fiberboards increased significantly with the increasing of the panel's density, and the IB value also increased from 0.43 to $0.67 \mathrm{MPa}$. This observed improvement is expected as the contact points among fibers increased with the increasing of panel's density. The SPI adhesives penetrated into the cells of fiber and interlocked with the fibers, so the combination between fibers and adhesives would be more closer. The data showed that the straw fiberboards produced with average density more than $0.8 \mathrm{~g} \mathrm{~cm}^{-3}$ had better mechanical properties, and the values of MOE and IB were $3.38 \mathrm{GPa}$ and $0.65 \mathrm{MPa}$ respectively, meeting the Chinese MDF Standard completely. The MOR of the panels could reach 25.5 MPa, which basically satisfies this standard.

3.5.2 Effect of fiberboards density on TS and WA of the straw fiberboards bonded with modified-SPI adhesive. The effect of fiberboard density on TS and WA of rice straw fiberboard was shown in Fig. 10. As the density of fiberboards increased, TS decreased from $34.24 \%$ to $22.49 \%$ and WA from $77.34 \%$ to $63.20 \%$. These decreases were probably due to the IB improvement with the increasing of fiberboard density; a better IB value meant that the combination between fibers and adhesives was very well, and the interspace among fibers would be much less, thus preventing water entering into the straw fiberboards. So the straw panels had good water-resistant properties when the density of fiberboard was greater than $0.80 \mathrm{~g} \mathrm{~cm}^{-3}$.
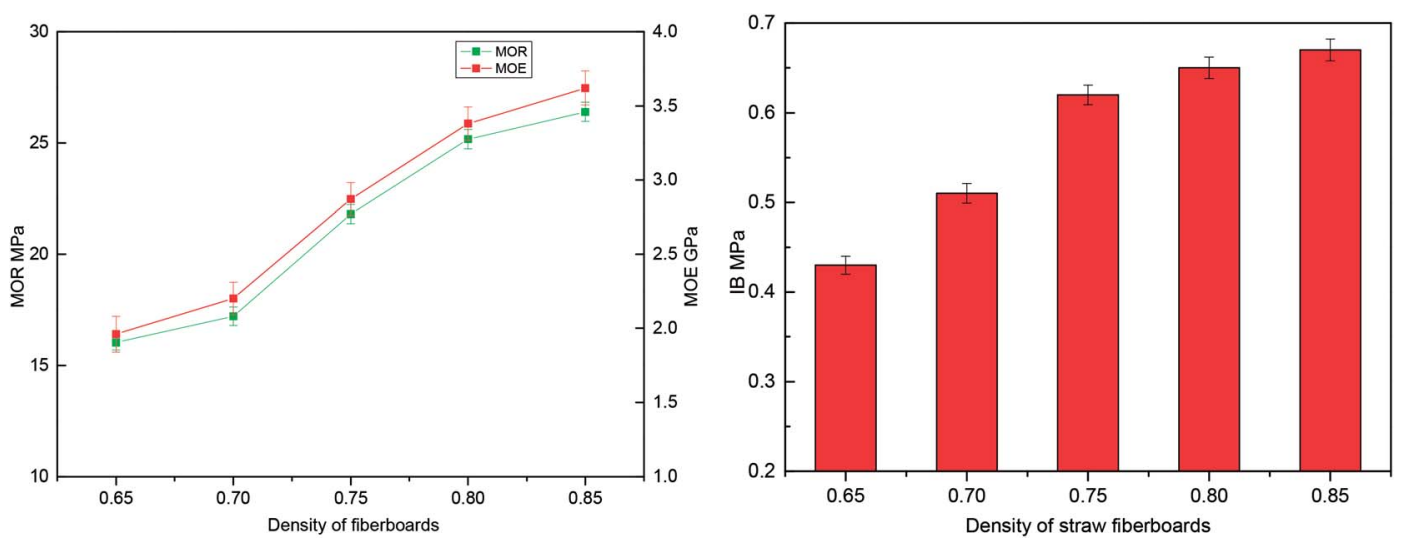

Fig. 9 Effect of fiberboard density on the MOR, MOE and IB of the straw fiberboards with modified-SPI adhesives. 


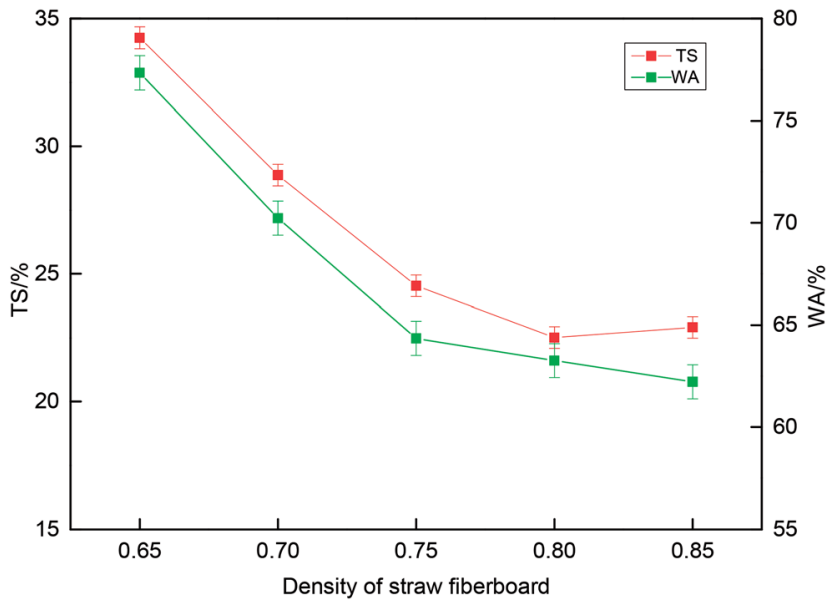

Fig. 10 Effect of fiberboard density on TS and WA values of the straw fiberboards with modified-SPI adhesives.

\subsection{TGA analysis}

Comparing straw fiberboards with straw fibers, there are some difference on their thermal properties. In this process, we use the thermogravimetric analysis (TGA) and derivative thermogravimetry (DTG) to investigate the thermal stability of straw fibers with $1 \% \mathrm{NaOH}$ pretreatment and straw fiberboards with $12 \mathrm{wt} \%$ modified-SPI adhesives bonded at a heating rate of $20{ }^{\circ} \mathrm{C} \min ^{-1}$.

In Fig. 11, we can see that both samples exhibited two-stage degradation. The first step which extended up to $150{ }^{\circ} \mathrm{C}$ was attributed to the evaporation of the retained residual water. Temperature range from $200{ }^{\circ} \mathrm{C}$ to $500{ }^{\circ} \mathrm{C}$ was the second stage. This stage involved the decomposition of modified soy protein, cellulose, hemicellulose and lignin in straw fibers. In the thermal decomposition curve of the straw fibers after $\mathrm{NaOH}$ treatment, the maximum speed of decomposition temperatures $\left(T_{\max }\right)$ was $345^{\circ} \mathrm{C}$, which was higher than that in the curve of soy protein-based adhesives bonded fiberboards $\left(339^{\circ} \mathrm{C}\right)$. The

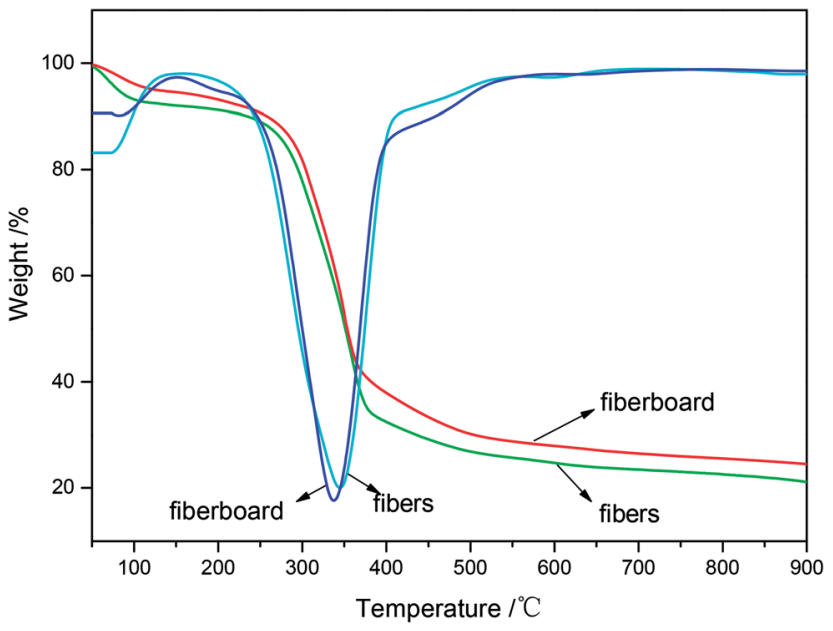

Fig. 11 TGA curves of straw fibers with $1 \% \mathrm{NaOH}$ pretreatment and fiberboard with $12 \mathrm{wt} \%$ modified-SPI adhesives. decrease of the $T_{\max }$ might be caused by the decomposition of modified soy protein, which had a lower $T_{\max }$ at $325{ }^{\circ} \mathrm{C}^{.26}$ After $360{ }^{\circ} \mathrm{C}$, the weight loss of fiberboard bonded with soy proteinbased adhesives was less than that in straw fibers curve, and the residue of the fiberboards bonded with soy protein-based adhesives was higher than that of straw fibers. These results support a conclusion that straw fibers bonded with modifiedSPI adhesives have higher thermal stability.

\section{Conclusions}

In this study, a kind of chemically-modified soy protein adhesive was prepared and used to bond the rice straw fiberboards. Urea and $\mathrm{NaOH}$ were used to pretreat the SPI, and epoxidized oleic acid was used to react with the amino groups in SPI molecular to improve the mechanical and water-resistant properties of adhesives. FTIR absorption peak at $1537 \mathrm{~cm}^{-1}$ disappeared and the peak at $1204 \mathrm{~cm}^{-1}$ was enhanced significantly that had proved viewpoint above. Meanwhile, the XRD peak at $2 \theta$ of $9^{\circ}$ disappeared wholly and a new peak appeared at approximately $12.5^{\circ}$. All of these results indicated the reaction between the epoxidized oleic acid and soy protein. FTIR and SEM results showed that, after $\mathrm{NaOH}$ pretreatment, the waxy layer of rice straw fibers were removed through chemical etching. According to mechanical and water absorption properties, when $\mathrm{NaOH}$ content was $1.0 \%$, the fiberboard had better comprehensive MOR, MOE, IB, TS and WA values, which was 21.8 $\mathrm{MPa}, 2.87 \mathrm{GPa}, 0.63 \mathrm{MPa}, 24.53 \%, 64.35 \%$ respectively. When the content of soy protein-based adhesives and density of fiberboard were $14 \%$ and $0.8 \mathrm{~g} \mathrm{~cm}^{-3}$, the panels have optimal mechanical and water-resistant performances. SEM images of the fractured surface of straw fiberboards illustrated that modified-SPI adhesives intimately contacted with the fibers. TGA analysis indicated that modified-SPI adhesive was beneficial to improve the thermal stability of straw fibers. The rice straw fiberboard is almost close to other wood fiberboards, and it possesses lower cost in the raw materials. ${ }^{27}$ On the whole, these fiberboards may replace petroleum-based resin panels and find applications in indoor decoration and furniture.

\section{Conflicts of interest}

There are no conflicts to declare.

\section{References}

1 T. Chapagain and A. Good, Front. Plant Sci., 2015, 6, 1-10.

2 P. Binod, R. Sindhu, R. R. Singhania, S. Vikram, L. Devi, S. Nagalakshmi, N. Kurien, R. K. Sukumaran and A. Pandey, Bioresour. Technol., 2010, 101, 4767-4774.

3 S. Sharma, R. Kumar, R. Gaur, R. Agrawal, R. Gupta, D. K. Tuli and B. Das, Bioresour. Technol., 2015, 175, 350-357.

4 R. Sindhu, M. Kuttiraja, T. P. Prabisha, P. Binod, R. K. Sukumaran and A. Pandey, Bioresour. Technol., 2015, 215, 110-116.

5 H. S. Yang, D. J. Kim and H. J. Kim, Bioresour. Technol., 2003, 86, 117-121. 
6 A. M. El-Kassas and A.-H. I. Mourad, Mater. Des., 2013, 50, 757-765.

7 E. D. Sitz and D. S. Bajwa, Ind. Crops Prod., 2015, 75, 200-205.

8 S. Halvarsson, H. Edlund and H. Norgrena, Bioresources, 2010, 5, 1215-1231.

9 Y. Liu and K. Li, Macromol. Rapid Commun., 2015, 23, 739742.

10 K. Nishinari, Y. Fang, S. Guo, R. Sukhotu, X. Shi and Q. Hu, Food Hydrocolloids, 2014, 39, 301-318.

11 C. S. Gui, G. Y. Wang, D. Wu, J. Zhu and X. Liu, Int. J. Adhes. Adhes., 2013, 44, 237-242.

12 Y. H. Zhang, W. Q. Zhu, Z. H. Gao and G. J. You, J. Appl. Polym. Sci., 2015, 132, 41387-41395.

13 Y. Jang and K. Li, J. Am. Oil Chem. Soc., 2015, 92, 431-438.

14 D. Vnučec, A. Goršek, A. Kutnar and M. Mikuljan, Wood Sci. Technol., 2015, 49, 225-239.

15 X. Q. Mo and S. S. Sun, J. Adhes. Sci. Technol., 2013, 27, 20142026.

16 C. F. D. Oliveira, A. P. F. Corrêa, D. Coletto, D. J. Daroit, F. C. Olivera and A. Brandelli, J. Food Sci. Technol., 2015, 52, 2668-2678.
17 N. R. Chen, Q. Z. Zeng, Q. J. Lin and J. Rao, Bioresources, 2015, 10, 5071-5082.

18 J. J. Li, J. Luo, X. N. Li, Z. Yi, Q. Gao and J. Li, Ind. Crops Prod., 2015, 74, 613-618.

19 J. L. Luo, J. Luo, X. N. Li, Q. Gao and J. Li, J. Appl. Polym. Sci., 2016, 13, 4362-4368.

20 Y. D. Li, S. C. Chen, B. J. Zeng and Y. Z. Wang, Ind. Eng. Chem. Res., 2008, 47, 8233-8238.

21 A. M. El-Kassas and A. H. I. Mourad, Mater. Des., 2013, 50, 757-765.

22 M. Jonoobi, M. Ghorbani, A. Azarhazin and H. Z. Hosseinabadi, Eur. J. Wood Wood Prod., 2017, 76, 517-524.

23 L. Zhang and Y. C. Hu, Mater. Des., 2014, 55, 19-26.

24 E. M. Ciannamea, J. F. Martucci, P. M. Stefani and R. A. Ruseckaite, J. Am. Oil Chem. Soc., 2012, 89, 1733-1741.

25 S. Vargas, J. R. Rodriquez, H. E. H. Lobland, K. Piechowicz and W. Brostow, Macromol. Mater. Eng., 2014, 299, 807-813.

26 W. S. Wang, Y. L. Guo and J. U. Otaigbe, Polymer, 2010, 51, 5448-5455.

27 J. Simonsen, R. Jacobsen and R. Rowell, J. Appl. Polym. Sci., 2015, 68, 1567-1573. 